\title{
An Evaluation of Ischaemic Preconditioning as a Method of Reducing Ischaemia Reperfusion Injury in Liver Surgery and Transplantation
}

\author{
Francis P. Robertson ${ }^{1, *} \mathbb{E}^{\mathbb{D}}$, Barry J. Fuller ${ }^{1}$ and Brian R. Davidson ${ }^{1,2}$ \\ 1 Division of Surgery and Interventional Science, Royal Free Campus, University College London, 9th Floor, \\ Royal Free Hospital, Pond Street, London NW3 2QG, UK; b.fuller@ucl.ac.uk (B.J.F.); \\ b.davidson@ucl.ac.uk (B.R.D.) \\ 2 Department of Hepaticopancreatobiliary Surgery and Liver Transplantation, Royal Free Foundation Trust, \\ 9th Floor, Royal Free Hospital, Pond Street, London NW3 2QG, UK \\ * Correspondence: francis.robertson.13@ucl.ac.uk; Tel.: +44-020-7794-0500
}

Received: 23 May 2017; Accepted: 4 July 2017; Published: 14 July 2017

\begin{abstract}
Liver Ischaemia Reperfusion (IR) injury is a major cause of post-operative liver dysfunction, morbidity and mortality following liver resection surgery and transplantation. There are no proven therapies for IR injury in clinical practice and new approaches are required. Ischaemic Preconditioning (IPC) can be applied in both a direct and remote fashion and has been shown to ameliorate IR injury in small animal models. Its translation into clinical practice has been difficult, primarily by a lack of knowledge regarding the dominant protective mechanisms that it employs. A review of all current studies would suggest that IPC/RIPC relies on creating a small tissue injury resulting in the release of adenosine and L-arginine which act through the Adenosine receptors and the haem-oxygenase and endothelial nitric oxide synthase systems to reduce hepatocyte necrosis and improve the hepatic microcirculation post reperfusion. The next key step is to determine how long the stimulus requires to precondition humans to allow sufficient injury to occur to release the potential mediators. This would open the door to a new therapeutic chapter in this field.
\end{abstract}

Keywords: Ischaemic Reperfusion injury; Ischaemic Preconditioning; Remote Ischaemic Preconditioning

\section{Introduction}

Ischaemia Reperfusion (IR) injury, the injury that happens to an organ when its blood supply is interrupted and re-established, is a major cause of post operative liver dysfunction, morbidity and mortality following liver transplantation and hepatic resectional surgery. Surgical and oncological advances in the treatment of colorectal liver metastases combined with an increase in obesity and aging populations in the West have led to an increase in major liver resectional surgery being performed on high risk patients. Similarly, the increased demand for liver transplantation combined with its proven success has led to a shortage of donor organs for transplant with the increased use of marginal quality grafts.

The presence of liver steatosis is associated with an increased risk of mortality from 2 to $14 \%$ following elective liver resection [1,2] and the use of a graft from a Donor following Circulatory Death (DCD) is associated with a twofold increase in risk of recipient death and graft loss [3]. This increased risk is secondary to the increased susceptibility of these livers to IR injury. There is currently no accepted treatment for IR injury and as such the development of strategies to ameliorate IR injury are necessary to make major liver surgery and liver transplantation safer. This would simultaneously allow the safe implantation of more marginal grafts that are currently rejected for transplantation due to the worry of Primary Graft Non Function (PGNF) resulting from severe IR injury. 
Ischaemic Preconditioning (IPC), the process by which short bursts of ischaemia to a vascular bed results in protection during further sustained ischaemic periods, is one such strategy which is directly applicable in the clinical setting. IPC can be either applied directly to the target organ [4] or remotely to a distant vascular bed [5]. Both forms of IPC have been shown to successfully ameliorate IR injury in small animal models. However the translation to clinical practice has led to conflicting results following an initial positive trial by Clavien [6,7] on patients undergoing hepatic resection, there have been several negative trials and some positive trials [8]. A recent meta-analysis failed to identify any benefit resulting from IPC performed in liver resections [9] however a meta-analysis of IPC performed on transplant donor livers prior to graft retrieval found evidence of a reduction in post-operative recipient mortality and graft loss [10]. A key factor in these conflicting results is a lack of understanding of the mechanisms by which IPC exerts its protective effects and as such IPC/RIPC protocols vary between studies and are unlikely to be optimal. Furthermore, IR injury in the setting of humans is more complex than in small animal models as multiple pathways overlap and can be altered secondary to the underlying condition. In small animal models, the animals are healthy and have little genetic variation, IR injury happens in patients often with severe systemic disease and multiple co morbidities. It is well known in cardiac patients and small animal models that diabetes, obesity and increased aged reduce the beneficial effect of preconditioning [11] but the effect of chronic liver disease remains unknown. Further complicating factors include blood loss and the need for transfusion during major liver surgery, as potential humoral factors may be lost or diluted and the type of anaesthetic used. Recently, in the setting of cardiac surgery, two large randomized controlled trials have failed to demonstrate a benefit following RIPC with both trials identifying the use of intravenous propofol (a very common anaesthetic agent used regularly in liver resection and transplantation) as a potential limitation $[12,13]$ and a small trial carried out by our group in the setting of liver transplantation [14] identifying that due to the use of high flow oxygen prevented the creation of true ischaemic conditions in the limb during the RIPC stimulus. As these essential intra-operative factors may impair the protection of RIPC knowledge of the various protective mechanisms is of key importance as this would not only allow IPC protocols in humans to be altered to overcome these hurdles but may also lead to new pathways that can be targeted to ameliorate IR injury bypassing these factors. The majority of basic research into IPC/RIPC has been performed in the myocardium. In this review, we present the mechanistic pathways identified in the protective effect of IPC/RIPC on liver IR injury.

\section{Methods}

Pubmed, Excerpta Medica Database (EMBASE) and Publicus Ovidus Naso (OVID) were searched between the years of 1986 and 2016 using the search strategy: (((liver) OR (hepatic)) AND ((ischemia) OR (ischemia-reperfusion injury)) AND ((preconditioning) OR (ischemic preconditioning) OR (IPC) OR (remote ischemic preconditioning) OR (RIPC) OR (hepatoprotection))). Key studies investigating the mechanisms of IPC/RIPC are contained in Table 1. 
Table 1. Studies investigating the mechanism of Ischaemic Preconditioning (IPC)/ Ischaemia Reperfusion Preconditioning (RIPC) in the setting of hepatic IR injury.

\begin{tabular}{|c|c|c|c|c|c|c|c|c|c|c|}
\hline Study Group & Year & Species & $\begin{array}{l}\text { IPC Time } \\
(\min )\end{array}$ & $\begin{array}{l}\text { Ischaemic } \\
\text { Time (min) }\end{array}$ & $\begin{array}{l}\text { Reperfusion } \\
\text { Time (min) }\end{array}$ & $\begin{array}{c}\text { Hepatic } \\
\text { Ischaemia }\end{array}$ & $\begin{array}{l}\text { Pharmacological } \\
\text { Manipulations }\end{array}$ & Parameters Assessed & Outcome of IPC & Proposed Mechanism \\
\hline \multicolumn{11}{|c|}{ Adenosine } \\
\hline Peralta [15] & 1997 & rat & 10 & 90 & 90 & partial & Adenosine and NO & $\begin{array}{c}\text { LFTs } \\
\text { Hepatic blood flow }\end{array}$ & $\begin{array}{c}\downarrow \text { LFTs } \\
\uparrow \text { blood flow }\end{array}$ & Adenosine/NO \\
\hline Peralta [16] & 1998 & rat & Variable & 90 & 90 & partial & Adenosine and NO & $\begin{array}{c}\text { LFTs } \\
\text { Adenosine } \\
\text { Inosine } \\
\text { Xanthine }\end{array}$ & $\begin{array}{c}\downarrow \text { LFTs } \\
\uparrow \text { Adenosine }\end{array}$ & Adenosine \\
\hline Nakayama [17] & 1999 & rat & 10 & 45 & Up to 7 days & unclear & $A_{1}$ and $A_{2}$ receptors & $\begin{array}{c}\text { LFTs } \\
7 \text { day survival } \\
\text { Adenosine }\end{array}$ & $\begin{array}{c}\uparrow 7 \text { day survival } \\
\downarrow \text { LFTs } \\
\uparrow \text { Adenosine }\end{array}$ & Adenosine via $\mathrm{A}_{2}$ receptor \\
\hline \multicolumn{11}{|c|}{$\mathrm{A}_{1}$ receptor } \\
\hline Peralta [18] & 1999 & rat & 10 & 90 & 90 & partial & $\mathrm{A}_{1}, \mathrm{~A}_{2}$ receptors and $\mathrm{NO}$ & $\begin{array}{c}\text { LFTs } \\
\text { Hepatic blood flow } \\
\text { NO production }\end{array}$ & $\begin{array}{c}\downarrow \text { LFTs } \\
\uparrow \text { blood flow } \\
\uparrow \text { NO production }\end{array}$ & $\begin{array}{l}\text { NO production through action of } \\
\text { adenosine on } \mathrm{A}_{2} \mathrm{R}\end{array}$ \\
\hline Ajamieh [19] & 2008 & rat & 10 & 90 & $24 \mathrm{~h}$ & partial & $\mathrm{A}_{1}$ receptor & $\begin{array}{c}\text { LFTs } \\
\text { TNF } \alpha \text { levels } \\
\text { MPO activity }\end{array}$ & $\begin{array}{c}\downarrow \text { LFTs } \\
\downarrow \text { TNF } \alpha \text { levels } \\
\downarrow \text { oxidative stress }\end{array}$ & $A_{1}$ receptor \\
\hline \multicolumn{11}{|c|}{$\mathrm{A}_{2 \mathrm{~A}}$ receptor } \\
\hline Perlata [18] & 1999 & rat & 10 & 90 & 90 & partial & $\mathrm{A}_{1}, \mathrm{~A}_{2}$ receptors and $\mathrm{NO}$ & $\begin{array}{l}\text { LFTs } \\
\text { Hepatic blood flow } \\
\text { NO production }\end{array}$ & $\begin{array}{c}\downarrow \text { LFTs } \\
\uparrow \text { blood flow } \\
\uparrow \text { NO production }\end{array}$ & $\begin{array}{l}\text { NO production through action of } \\
\text { adenosine on } \mathrm{A}_{2} \mathrm{R}\end{array}$ \\
\hline Schaeur [20] & 2003 & rat & 10 & 90 & 120 & partial & $\mathrm{A}_{2 \mathrm{~A}}$ receptor and $\mathrm{p} 38 \mathrm{MAPK}$ & $\begin{array}{c}\text { LFTs } \\
\text { Hepatic perfusion }\end{array}$ & $\begin{array}{c}\downarrow \downarrow \text { LFTs } \\
\downarrow \text { KC induce liver damage }\end{array}$ & $\begin{array}{l}\text { p38 MAPK stimulation not } \mathrm{A}_{2 \mathrm{~A}} \\
\text { receptor }\end{array}$ \\
\hline \multicolumn{11}{|c|}{$\mathrm{A}_{2 \mathrm{~B}}$ receptor } \\
\hline Chouker [21] & 2012 & mouse & 10 & 45 & 240 & partial & $\mathrm{A}_{2 \mathrm{~A}}, \mathrm{~A}_{2 \mathrm{~B}}$ receptors & $\begin{array}{l}\text { LFTs } \\
\text { TNF } \alpha \text { levels } \\
\text { IL-6 levels }\end{array}$ & $\begin{array}{c}\downarrow \text { LFTs } \\
\downarrow \text { TNF } \alpha \text { levels } \\
\downarrow \text { IL-6 levels }\end{array}$ & $\mathrm{A}_{2 \mathrm{~B}}$ receptor but not $\mathrm{A}_{2 \mathrm{~A}}$ receptor \\
\hline \multicolumn{11}{|c|}{$A_{3}$ receptor } \\
\hline \multicolumn{11}{|c|}{ None } \\
\hline \multicolumn{11}{|c|}{ eNOS } \\
\hline Koti [22] & 2005 & rat & 5 & 45 & 120 & partial & $\mathrm{L}$-arginine and $\mathrm{NO}$ & $\begin{array}{l}\text { LFTs } \\
\text { NO } \\
\text { eNOS } \\
\text { iNOS } \\
\end{array}$ & $\begin{array}{c}\downarrow \text { LFTs } \\
\uparrow \text { NO levels } \\
\uparrow \text { eNOS } \\
\text { no change in iNOS } \\
\end{array}$ & $\begin{array}{l}\text { NO formed from eNOS is } \\
\text { hepatoprotective }\end{array}$ \\
\hline Abu-Amara [23] & 2011 & mouse & 4 & 40 & 120 & partial & eNOS genetic knockout & $\begin{array}{c}\text { LFTs } \\
\text { Hepatic blood flow } \\
\text { Pathological injurye } \\
\text { NOS expression }\end{array}$ & $\begin{array}{c}\downarrow \text { LFTs } \\
\downarrow \text { injury } \\
\text { eNOS expression not } \\
\text { upregulated in wild type mice. }\end{array}$ & $\begin{array}{l}\text { RIPC provided no protection in } \\
\text { eNOS }-/- \text { mice } \\
\text { RIPC did not upregulate eNOS } \\
\text { expression in wild type mice }\end{array}$ \\
\hline
\end{tabular}


Table 1. Cont.

\begin{tabular}{|c|c|c|c|c|c|c|c|c|c|c|}
\hline Study Group & Year & Species & $\begin{array}{l}\text { IPC Time } \\
(\mathrm{min})\end{array}$ & $\begin{array}{l}\text { Ischaemic } \\
\text { Time (min) }\end{array}$ & $\begin{array}{l}\text { Reperfusion } \\
\text { Time (min) }\end{array}$ & $\begin{array}{c}\text { Hepatic } \\
\text { Ischaemia }\end{array}$ & $\begin{array}{c}\text { Pharmacological } \\
\text { Manipulations }\end{array}$ & Parameters Assessed & Outcome of IPC & Proposed Mechanism \\
\hline \multicolumn{11}{|c|}{ iNOS } \\
\hline Koti [22] & 2005 & rat & 5 & 45 & 120 & partial & L-arginine and NO & $\begin{array}{l}\text { LFTs } \\
\text { NO } \\
\text { eNOS } \\
\text { iNOS }\end{array}$ & $\begin{array}{c}\downarrow \text { LFTs } \\
\uparrow \text { NO levels } \\
\uparrow \text { eNOS } \\
\text { no change in iNOS }\end{array}$ & $\begin{array}{l}\text { NO formed from eNOS is } \\
\text { hepatoprotective }\end{array}$ \\
\hline \multicolumn{11}{|c|}{ PKC } \\
\hline Carini [24] & 2000 & rat & 10 & 90 & 0 & hepatocytes & PKC & $\begin{array}{l}\text { Intracellular } \mathrm{pH} \\
\text { Intracellualar Na } \\
\text { Cell viability } \\
\end{array}$ & $\begin{array}{c}\uparrow \text { cell survival } \\
\downarrow \mathrm{pH} \\
\downarrow \text { Na accumulation } \\
\end{array}$ & PKC necessary to allow IPC \\
\hline Carini [25] & 2001 & rat & 10 & 90 & 90 & hepatocytes & $\mathrm{A}_{2 \mathrm{~A}}$ receptor and $\mathrm{PKC}$ & $\begin{array}{l}\text { Cell viability } \\
\text { PK levels }\end{array}$ & $\begin{array}{c}\uparrow \text { cell survival } \\
\uparrow \mathrm{p} 38 \text { MAPK phosphorylation }\end{array}$ & $\begin{array}{l}\text { PKC activation following } \mathrm{A}_{2 \mathrm{~A}} \\
\text { receptor stimulation }\end{array}$ \\
\hline Ricciardi [26] & 2001 & pig & 15 & 120 & 240 & total & РКС & $\begin{array}{l}\text { Graft function } \\
\text { Hepatic perfusion } \\
\text { Graft injury }\end{array}$ & $\begin{array}{c}\uparrow \text { Graft function } \\
\uparrow \text { Hepatic perfusion } \\
\downarrow \text { Graft injury }\end{array}$ & $\begin{array}{l}\text { PKC translocation to nucleus is } \\
\text { necessary for IPC }\end{array}$ \\
\hline \multicolumn{11}{|c|}{ NF-kB } \\
\hline Ricciardi [27] & 2002 & pig & 15 & 120 & 240 & total & PKC & NF-kB & $\uparrow \mathrm{NF}-\mathrm{kB}$ & IPC increases translocation of NF-kB \\
\hline \multicolumn{11}{|c|}{ HO-1 } \\
\hline Lai [28] & 2006 & rat & 10 & 45 & 240 & partial & HO-1 & $\begin{array}{c}\text { LFTs } \\
\text { HO-1 expression } \\
\text { HO activity }\end{array}$ & $\begin{array}{c}\downarrow \text { LFTs } \\
\uparrow \text { HO- } 1 \text { expression } \\
\uparrow \text { HO activity }\end{array}$ & $\begin{array}{l}\text { RIPC increases HO-1 expression and } \\
\text { activity }\end{array}$ \\
\hline Datta [29] & 2014 & mouse & 5 & 45 & 120 & partial & eNOS genetic knockout & $\begin{array}{c}\text { LFTs } \\
\text { Hepatic perfusion } \\
\text { HO-1 expression }\end{array}$ & $\begin{array}{c}\downarrow \text { LFTs } \\
\uparrow \text { Hepatic perfusion }\end{array}$ & $\begin{array}{l}\text { eNOS- / - mice had reduced effect } \\
\text { from IPC. HO-1 mRNA no } \\
\text { significantly increased by IPC }\end{array}$ \\
\hline Wang [30] & 2014 & mouse & 4 & 45 & $24 \mathrm{~h}$ & partial & HO-1 & $\begin{array}{c}\text { LFTs } \\
\text { HO-1 expression } \\
\text { Autophagy } \\
\end{array}$ & $\begin{array}{c}\downarrow \text { LFTs } \\
\uparrow \text { HO-1 expression } \\
\uparrow \text { Autophagy }\end{array}$ & $\begin{array}{l}\text { RIPC lead to increased autophagy in } \\
\text { a HO-1 dependant manner }\end{array}$ \\
\hline \multicolumn{11}{|c|}{ Tregs } \\
\hline Kinsey [31] & 2010 & mouse & 24 (bilateral) & $\begin{array}{l}28(7 \text { days } \\
\text { post IPC })\end{array}$ & unclear & $\begin{array}{c}\text { Renal } \\
\text { (1 kidney) }\end{array}$ & $\begin{array}{l}\text { Treg depletion and adoptive } \\
\text { transfer }\end{array}$ & $\begin{array}{l}\text { Serum creatinine } \\
\text { Renal Treg number } \\
\text { and IL-10 production }\end{array}$ & $\begin{array}{c}\downarrow \text { Creatinine } \\
\uparrow \text { Treg accumulation } \\
\uparrow \text { Treg IL-10 production }\end{array}$ & $\begin{array}{l}\text { Treg accumulation took } 7 \text { days. Treg } \\
\text { depletion ablated effect of IPC }\end{array}$ \\
\hline Cho [32] & 2010 & mouse & 24 (bilateral) & $\begin{array}{l}28(7 \text { days } \\
\text { post IPC })\end{array}$ & $24 \mathrm{~h}$ & $\begin{array}{c}\text { Renal } \\
\text { (1 kidney) }\end{array}$ & $\begin{array}{l}\text { Treg depletion and adoptive } \\
\text { transfer }\end{array}$ & $\begin{array}{l}\text { Serum creatinine } \\
\text { Treg number } \\
\text { Splenocytes cytokine } \\
\text { and proliferation } \\
\end{array}$ & $\begin{array}{c}\downarrow \text { Creatinine } \\
\uparrow \text { Treg accumulation } \\
\downarrow \text { Splenocyte proliferation and } \\
\text { cytokine production }\end{array}$ & $\begin{array}{c}\text { Treg depletion ablated effect of IPC. } \\
\text { Stimulated lymphocytes from mice } \\
\text { undergoing IIC were less } \\
\text { pro-inflammatory. }\end{array}$ \\
\hline Devey [33] & 2012 & mouse & 15 & 50 & $24 \mathrm{~h}$ & partial & $\begin{array}{l}\text { Treg depletion and adoptive } \\
\text { transfer }\end{array}$ & $\begin{array}{c}\text { LFTs } \\
\text { Treg numbers } \\
\text { Circulating cytokines }\end{array}$ & $\begin{array}{c}\downarrow \text { LFTs } \\
\text { Treg recruitment }\end{array}$ & IPC mechanism not related to Tregs \\
\hline \multicolumn{11}{|c|}{ Macrophages } \\
\hline Peralta [34] & 1999 & rat & 10 & 90 & 90 & partial & $\begin{array}{l}\text { TNF } \alpha \text { treatment and } \\
\text { macrophage depletion with } \\
\text { Gadolinium Chloride. }\end{array}$ & $\begin{array}{l}\text { LFTs } \\
\text { Hepatic oedema } \\
\text { TNF } \alpha \text { release }\end{array}$ & $\begin{array}{c}\downarrow \text { LFTs } \\
\downarrow \text { TNF } \alpha \text { release } \\
\downarrow \text { hepatic oedema }\end{array}$ & $\begin{array}{l}\mathrm{TNF} \alpha \text { production by macrophages } \\
\text { drives hepatic IR injury }\end{array}$ \\
\hline
\end{tabular}


Table 1. Cont.

\begin{tabular}{|c|c|c|c|c|c|c|c|c|c|c|}
\hline Study Group & Year & Species & $\begin{array}{c}\text { IPC Time } \\
(\min )\end{array}$ & $\begin{array}{l}\text { Ischaemic } \\
\text { Time (min) }\end{array}$ & $\begin{array}{l}\text { Reperfusion } \\
\text { Time (min) }\end{array}$ & $\begin{array}{c}\text { Hepatic } \\
\text { Ischaemia }\end{array}$ & $\begin{array}{c}\text { Pharmacological } \\
\text { Manipulations }\end{array}$ & Parameters Assessed & Outcome of IPC & Proposed Mechanism \\
\hline Peralta [35] & 2001 & rat & 19 & 90 & 90 & partial & $\begin{array}{l}\text { Antibody inhibition of I-CAM } \\
\text { and macrophage depletion } \\
\text { with Gadolinium Chloride }\end{array}$ & $\begin{array}{c}\text { LFTs } \\
\text { Neutrophil } \\
\text { accumulation and } \\
\text { activity in distant } \\
\text { organs }\end{array}$ & $\begin{array}{l}\downarrow \text { neutrophil accumulation and } \\
\text { activity in distant end organs }\end{array}$ & $\begin{array}{l}\text { IPC reduce neutrophil infiltration } \\
\text { into distant organs but not the liver } \\
\text { itself. Likely secondary to } \\
\text { macrophage TNF } \alpha \text { production }\end{array}$ \\
\hline Glanemann [36] & 2003 & rat & 5 & 45 & 90 & global & Nil & $\begin{array}{c}\text { LFTs } \\
\text { Kupffer cell } \\
\text { phagocytosis } \\
\text { Hepatic perfusion } \\
\text { and oxygenation }\end{array}$ & $\begin{array}{c}\downarrow \text { LFTs } \\
\downarrow \text { Kupffer cell activation } \\
\uparrow \text { hepatic perfusion and } \\
\text { oxygenation }\end{array}$ & $\begin{array}{l}\text { IPC reduction macrophage } \\
\text { activation in early staged of IR injury }\end{array}$ \\
\hline Tejima [37] & 2004 & rat & 10 & 40 & 60 & partial & $\begin{array}{l}\text { Macrophage depletion with } \\
\text { Gadolinium Chloride and } \\
\text { treatment with anti-oxidants }\end{array}$ & $\begin{array}{c}\text { LFTs } \\
\begin{array}{l}\text { Sinusoidal epithelial } \\
\text { cell injury }\end{array} \\
\end{array}$ & $\begin{array}{c}\downarrow \text { LFTs } \\
\text { no change in sinusoidal } \\
\text { epithelial cell injury }\end{array}$ & $\begin{array}{l}\text { Macrophages were essential for the } \\
\text { preconditioning stimulus to be } \\
\text { effective }\end{array}$ \\
\hline \multicolumn{11}{|c|}{ Cytokines } \\
\hline Funaki [38] & 2002 & mouse & 15 & 70 & 240 & global & $\begin{array}{l}\text { NF-kB an tyrosine kinase } \\
\text { inhibition }\end{array}$ & Hepatic TNF $\alpha$ & $\downarrow \mathrm{TNF} \alpha$ & IPC reduced hepatic TNF $\alpha$ levels \\
\hline Zhu [39] & 2003 & rat & 10 & 240 (cold) & $24 \mathrm{~h}$ & global & nil & $\begin{array}{l}\text { LFTs } \\
\text { Serum TNF } \alpha \\
\text { Apoptosis }\end{array}$ & $\begin{array}{c}\downarrow \text { LFTs } \\
\downarrow \text { TNF } \alpha \\
\downarrow \text { Apoptosis }\end{array}$ & $\begin{array}{l}\text { IPC lead to reduced apoptosis and } \\
\text { TNF } \alpha \text { release }\end{array}$ \\
\hline Yao [40] & 2007 & rat & 10 & 55 & 7 days & global & nil & $\begin{array}{c}\text { Survival } \\
\text { LFTs } \\
\text { Hepatic IL-6 } \\
\text { Hepatic TNF } \alpha \\
\end{array}$ & $\begin{array}{c}\text { No change in survival } \\
\uparrow \text { LFTs } \\
\text { No change in TNF } \alpha \\
\downarrow \text { IL- } 6\end{array}$ & $\begin{array}{l}\text { IPC increased IR injury in small for } \\
\text { size grafts }\end{array}$ \\
\hline Koneru [41] & 2007 & human & 10 & $329-505$ & $\mathrm{n} / \mathrm{a}$ & global & nil & $\begin{array}{c}\text { Survival } \\
\text { LFTs } \\
\text { Post-op complications } \\
\text { Serum TNF } \alpha \\
\text { Serum IL-6 } \\
\text { Serum IL-10 } \\
\end{array}$ & $\begin{array}{c}\text { No change in survival } \\
\uparrow \text { LFTs in the first } 2 \text { days } \\
\downarrow \text { episodes of acute rejection } \\
\uparrow \text { IL-10 levels post reperfusion } \\
\text { No change in TNF } \alpha \text { or } \\
\text { IL-6 levels } \\
\end{array}$ & \\
\hline Ajamieh [19] & 2008 & rat & 10 & 90 & $24 \mathrm{~h}$ & partial & $A_{1}$ receptor & $\begin{array}{c}\text { LFTs } \\
\text { TNF } \alpha \text { levels } \\
\text { MPO activity }\end{array}$ & $\begin{array}{c}\downarrow \text { LFTs } \\
\downarrow \text { TNF } \alpha \text { levels } \\
\downarrow \text { oxidative stress } \\
\end{array}$ & $A_{1}$ receptor \\
\hline Guimaraes [42] & 2015 & rat & 4 & 45 & 180 & partial & nil & $\begin{array}{c}\text { LFTs } \\
\text { Serum IL-6 } \\
\text { Serum IL-10 }\end{array}$ & $\begin{array}{c}\quad \downarrow \text { LFTs } \\
\uparrow \text { IL-6 at } 1 \mathrm{~h} \\
\downarrow \downarrow \\
\downarrow \text { IL-6 at } 3 \mathrm{~h}\end{array}$ & $\begin{array}{l}\text { IL-6 levels were raised } 1 \mathrm{~h} \text { post IPC } \\
\text { but were significantly less at } 3 \mathrm{~h}\end{array}$ \\
\hline Li [43] & 2016 & mouse & 10 & 120 (cold) & 3 days & global & nil & $\begin{array}{l}\text { Survival } \\
\text { LFTs } \\
\text { Serum TNF } \alpha \\
\text { Innate immune } \\
\text { response } \\
\end{array}$ & $\begin{array}{c}\text { No change in survival } \\
\downarrow \text { LFTs } \\
\downarrow \text { TNF } \\
\downarrow \text { Apoptosis } \\
\end{array}$ & $\begin{array}{l}\text { IPC reduced liver injury but did not } \\
\text { improve survival }\end{array}$ \\
\hline
\end{tabular}

Abbreviations used: eNOS (endothelial Nitric Oxide Synthase), HO-1 (Heam-oxygenase-1)iNOS (inducible Nitric Oxide Syntase), KC (Kupffer Cells), LFT's (Liver Function Tests), MAPK

(Mitogen-activated Protein Kinases), MPO (Myeloperoxidase), NF- KB (Nuclear Factor kappa-light-chain-enhancer-of B cells), NO (Nitric Oxide), PK (Protein Kinase) TNF $\alpha$ (Tumour

Necrosis Factor alpha), Tregs (regulatory T cells). 


\section{Protective Effects of Preconditioning}

Although there is clear evidence in the setting of myocardial IR injury to suggest that IPC exerts its maximal effect in the immediate post reperfusion period [44], it is known that IPC has a bimodal duration of protection. There appears to be an early (or classic) window of protection lasting up to $3 \mathrm{~h}$ and a later period of protection lasting between 12 and $72 \mathrm{~h}$ post preconditioning-the so-called second window of protection (SWOP) [45-47]. The mechanisms by which IPC exerts it protection during these phases are poorly understood but have been shown to be very different in the two time periods. The phenomenon of the SWOP, although a focus of cardiac IPC studies has not been the focus of studies in hepatic IR injury, in which IPC/RIPC is generally performed $5 \mathrm{~min}$ before IR injury. This review will focus mainly on the classical protective window.

IPC has been postulated to work through three main generic mechanisms (Figure 1). IPC has been shown to release humoral factors into the blood which reduce apoptosis and cell death in the target organ during the IR injury. It has also been shown to reduce the systemic inflammatory response following IR injury further reducing tissue injury. It has been shown in other organs that RIPC relies on a neuronal feedback mechanism to provide protection and that interruption nervous system either physically or pharmacologically can block RIPC [48]. This pathway has not been investigated in the setting of liver IR injury.

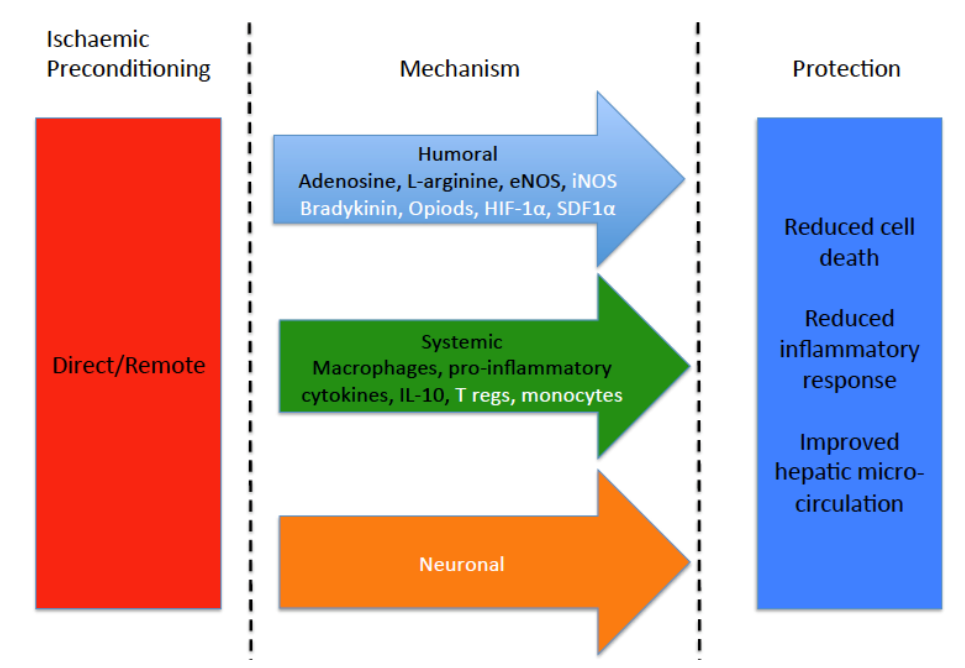

Figure 1. Previously identified mechanism of IPC. Mechanisms identified in the setting of liver IR injury are in black whilst those not implicated/researched are in white.

\section{Adenosine}

Adenosine, a nucleotide and component of ATP breakdown, is rapidly released from damaged cells in ischaemic tissue [49] and can bind with four different adenosine receptors $\left(A_{1} R, A_{2 A} R, A_{2 B} R\right.$, and $A_{3} R$ ) [50], all of which can be expressed by hepatocytes [51]. As in other organs [51], Adenosine has been shown to play a protective effect in the liver following IR injury through a diverse range of mechanisms (Figure 2). Pharmacological upregulation of endogenous adenosine by R75231 (which prevents adenosine uptake and metabolism) significantly attenuated liver IR injury in a canine model and led to significantly increased survival at two weeks following $2 \mathrm{~h}$ of total liver ischaemia [52]. In rats treated with adenosine deaminase (which degrades adenosine) prior to IPC, the protective effect of IPC was abolished in hepatic IR injury as measured by serum transaminases and lactate dehydrogenase [15]. Conversely, administration of a NO donor in these animal reinstated the protective effect which is in keeping with the knowledge that adenosine leads to NO release by the vascular endothelium, resulting in vasodilation [53]. The same group demonstrated that IPC increased levels of adenosine in the hepatic tissue [16] and this has been confirmed in one study [17]. The administration 
of adenosine deaminase abolished the protective effect of IPC and adenosine infusion prior to IR injury provided protection to a similar level as IPC [16]. An interesting observation by Peralta and colleagues was that 10-15 min of continuous ischaemic stimulus in IPC was the ideal length of time in rats as it lead to sufficient release of adenosine but insufficient release of other toxic metabolites of ischaemia [16]. This is in keeping with studies of IPC on donor livers prior to retrieval in human liver transplantation in which it was demonstrated that $5 \mathrm{~min}$ of donor preconditioning was insufficient to provide protection [54] whilst $10 \mathrm{~min}$ of donor IPC was associated with a reduction in postoperative transaminases in keeping with a reduction in IR injury [55], a finding also found in patients undergoing RIPC prior to major hepatectomy [8]. There is clear evidence that adenosine is upregulated following IPC/RIPC and that pharmacological degradation of adenosine ablated the protective effect of IPC. Adenosine exerts its anti-apoptotic and vasodilatary effect through its interaction with the adenosine receptors. In keeping with studies into IR injury in other organs, much of the work on these receptors has focused on the $A_{1}$ and the $A_{2 A}$ receptors.

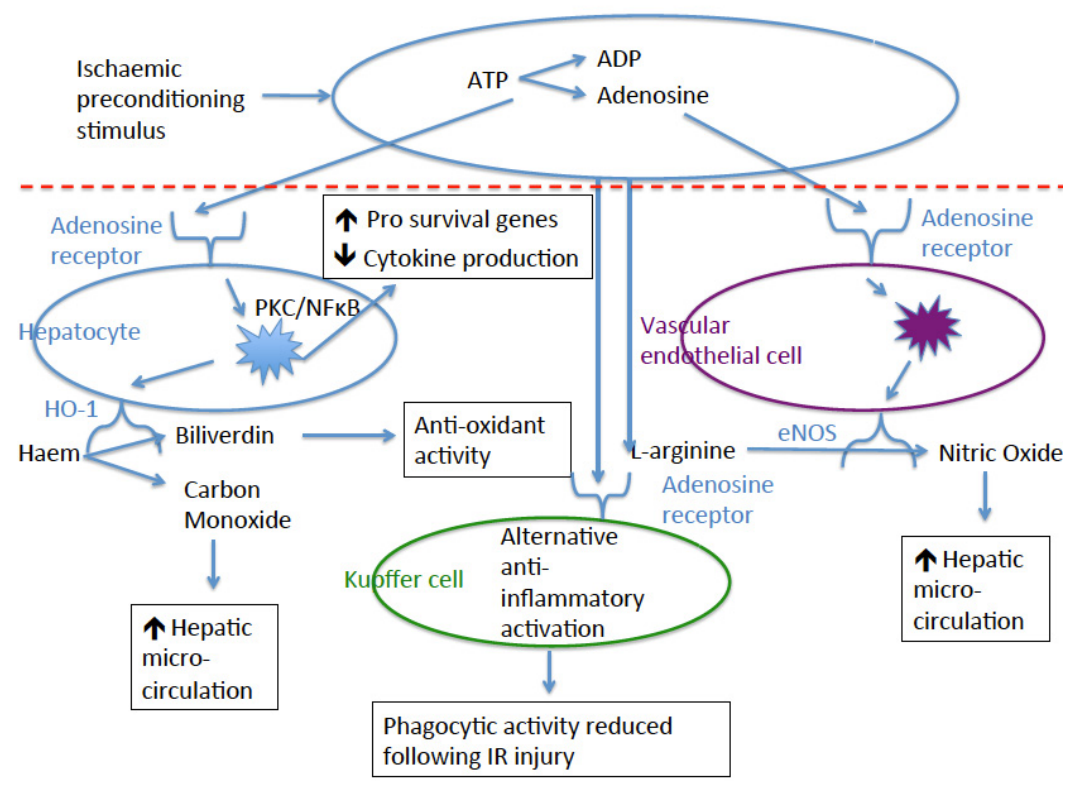

Figure 2. Protective mechanisms of adenosine release following Ischaemic Preconditioning (IPC).

\section{The $A_{1}$ Receptor}

Genetic knockout mice lacking the $A_{1}$ receptor are more susceptible to hepatic IR injury than wild type mice with a normal $A_{1} R$ [56]. This was linked to a significant increase in the level of apoptosis and neutrophil infiltration seen within the liver at 12 and $24 \mathrm{~h}$. Selective blockade of $A_{1} R$ with 8-Cyclopentyl-1, 3-dpropylxanthine (DPCPX) also increased IR injury as measured by serum transaminases and hepatic necrosis [56]. In contrast, beagles administered the $A_{1} R$ antagonist (KW3902) had reduced transaminases, better hepatic blood flow upon reperfusion and significantly improved two-week survival following hepatic IR injury ( $83 \%$ vs. $17 \%, p<0.05)$ [57]. It is unclear why there is such a striking difference between the studies on the $A_{1}$ receptor but this may reflect the different species or the use of a different $A_{1} R$ antagonist.

Adenosine or its receptors may also play a role in the protective effect of IPC. However some of the results have been conflicting. Ajemieh and colleagues [19] demonstrated that in rats treated with the $\mathrm{A}_{1} \mathrm{R}$ antagonist, DPCPX, the protective effect of IPC was ablated. Similarly treatment of rats with CCPA (an $\mathrm{A}_{1} \mathrm{R}$ agonist) provided a similar level of protection following IR injury as garnered by IPC. This was in contrast to findings from Peralta and colleagues [18] who demonstrated that, although adenosine depletion negated the protective effects of IPC and improved hepatic blood flow post reperfusion, pharmacological inhibition of the $\mathrm{A}_{1} \mathrm{R}$ with DPCPX did not affect the protection produced by IPC. The 
timing of DPCPX administration between these studies differs. It was administered 5 min prior to IPC by Perlata [18] and $24 \mathrm{~h}$ prior to IPC by Ajemieh and colleagues [19] which may explain the different results. Both studies used a dose of $0.1 \mathrm{mg} / \mathrm{kg}$. In none of the above studies did treatment of the animals with an $A_{1} R$ agonist lead to protection of the liver during IR injury prompting the suggestion that IPC required the presence or upregulation of endogenous adenosine [19] or other mediators.

\section{The $\mathrm{A}_{2 \mathrm{~A}}$ Receptor}

The $\mathrm{A}_{2 \mathrm{~A}}$ Receptor has been shown to play a key role in hepatic IR injury as the administration of the $A_{2 A} R$ agonist $\gamma$-glutamylcysteine synthase (GCS) to isolated rat livers immediately prior to reperfusion reduced the level of apoptosis and degree of liver IR injury as measured by transaminases and degree of hepatocyte apoptosis [58].

IPC has been shown indirectly to exert protection through the $A_{2 A} R$ in several studies. Perlata and colleagues [18] demonstrated that the use of DMPX, an $\mathrm{A}_{2} \mathrm{R}$ antagonist (at this time point, there was no distinction between $A_{2 A} R$ and $A_{2 B} R$ ), ablated the protective effect of IPC in a rat model. Thurman and colleagues [59] demonstrated again that the administration of DMPX ablated the protective effect of IPC but also they were one of few groups who demonstrated that the administration of CGS-21680, an $A_{2} R$ agonist, protected the liver against IR injury. Their results would suggest that IPC prevented sinusoidal epithelial cell death through the adenosine receptors. However, in contrast, Schaeur and colleagues [20] demonstrated that the use of DMPX had no effect on the protective effect of IPC. Adenosine has been shown to exert its protective effect through reduced hepatocyte apoptosis and increased hepatic blood flow post reperfusion. It has also been shown to play a role in directing the early immune response post reperfusion [60] and mice treated with an $A_{2 A} R$ agonist (ATL146e) not only had a significantly reduced IR injury but also had less upregulation of pro-inflammatory cytokines including IL-6 and MCP-1. The activation of Natural Killer T cells was inhibited through activation of the $A_{2 A} R$ [61] again suggesting that adenosine is able to suppress the post reperfusion inflammatory response. Whether this is as a result of reduced necrosis or directly suppressing inflammation remains to be elucidated as the effect of IPC on NKT cell differentiation and activation has not been investigated.

\section{The $A_{2 B}$ Receptor}

Few studies have investigated the role of the $A_{2 B} R$ in hepatic IR injury. Zimmerman and colleagues [62] demonstrated that the $A_{2 B} R$ was upregulated on human hepatocytes in post reperfusion liver biopsies when compared to the same livers pre implantation. Furthermore, they showed that mice lacking the $\mathrm{A}_{2 \mathrm{~B}} \mathrm{R}$ suffered significantly worse IR injury following 45 min of warm IR injury and that this was associated with higher levels of IL- 6 and TNF $\alpha$ production in the liver and distant end organs. Analysis using cell culture demonstrated that activation of the $A_{2 B} R$ reduced NF- $\kappa B$ activation and stabilization in hepatocytes and that pharmacological stabilisation of NF- $\mathrm{kB}$ reconstituted the injury in $\mathrm{A}_{2 \mathrm{~B}} \mathrm{R}$ deficient mice. In a study of global hypoxic preconditioning in which mice were subjected to $10 \%$ Oxygen for 10 min prior to hepatic IR injury, it was shown that mice lacking the $A_{2 B} R$ were not protected while mice lacking each of the other three receptors were still protected [21]. Although reduction in IR injury was associated a reduction in IL-6, TNF $\alpha$ levels and neutrophil infiltration, no down stream mechanisms were explored.

\section{The $A_{3}$ Receptor}

There is no evidence as yet regarding the role of the $A_{3} R$ either in hepatic IR injury or in IPC of the liver.

\section{Adenosine and Its Receptors}

The seemingly conflicting results from studies investigating the individual adenosine receptors would suggest that it is more likely that the mechanism of protection of IPC is related to increased adenosine release rather than upregulation of an individual receptor. 


\section{Nitric Oxide and Nitric Oxide Synthase}

Nitric oxide (NO), a potent vasodilator, is a colourless gas synthesized by the action of Nitric Oxide Synthase (NOS) on L-arginine [63] and has been shown to exert a protective effect during hepatic IR injury [64] by inhibiting synthesis of endothelin, a potent vasoconstrictor [65]. There are three isoforms of NOS. Only two are believed to play a role in hepatic IR injury: endothelial nitric oxide syntase (eNOS) and inducible nitric oxide syntase (iNOS).

There is robust evidence demonstrating that NO derived from eNOS is hepatoprotective following IR injury. Transgenic mice lacking eNOS have been shown to suffer a more significant IR injury [66-70] whilst genetic over expression of eNOS in mice is associated with a significant reduction in IR injury [71].

In the setting of IPC, eNOS expression and circulating levels of L-arginine were upregulated in the rodent liver following IPC and this was associated with increased nitrate levels in the portal vein [22]. Pre treatment with DMPX, an adenosine A2 inhibitor, abolished the protective effect of IPC. There was no upregulation of eNOS and the results were similar to those seen when rats were treated with L-NAME, a NOS inhibitor, suggesting that eNOS upregulation and function is reliant on the $\mathrm{A}_{2} \mathrm{R}$ pathway [64]. These results were similar to the findings of Mathie and colleagues [72] who demonstrated that administration of adenosine was able to ameliorate IR injury but that when combined with L-NA, an eNOS inhibitor, adenosine was unable to provide protection [72]. Transgenic mice lacking eNOS that underwent RIPC displayed the same level of hepatic IR injury as those undergoing IR injury without RIPC again confirming the key role eNOS in the early protection of RIPC [23].

The effect of NO from iNOS in hepatic IR injury is more variable. Some studies have suggested that the effect of iNOS activation is dependent on the length of the ischaemic period and temperature maintained during ischaemia [63], however several studies have shown that NO derived from iNOS is a key mechanism of liver injury following IR injury [73,74]. Targeting eNOS rather than NO may therefore be more beneficial.

IPC of the liver has not been shown to affect iNOS levels [22] suggesting the iNOS does not play a role in the protective mechanisms of IPC/RIPC.

\section{Protein Kinase C}

The term protein kinase $\mathrm{C}$ (PKC) encompasses a family of intracellular enzymes that can be classified as signal transducers that direct the processing of downstream proteins. PKC induction in hepatocytes has been shown to be significantly elevated in rodent livers following reperfusion [75]. PKC has been identified as a downstream signalling pathway of adenosine receptors [76,77]. Pharmacological inhibition of PKC has been shown to reduce hepatic IR injury $[26,78,79]$.

Interestingly, studies investigating the effect of IPC on PKC activity have shown that the protective effect of IPC is not associated with inhibition of PKC but actually with an increase in PKC activity. In an isolated hepatocyte model, it was shown that the protective effect of hypoxic preconditioning was ablated by the use of a PKC inhibitor chelerythrine [24]. Further similar work by the same group on isolated rodent hepatocytes confirmed these findings but also linked PKC activation to the $\mathrm{A}_{2} \mathrm{R}$ [77]. In pig livers undergoing IPC, prior to cold storage, PKC was shown to be activated in the hepatocytes of livers undergoing IPC prior to cold storage [26]. Treatment of livers with chelerythrine was shown to abolish the protective effects of IPC [26]. Other intracellular kinases have been implicated including tyrosine kinase [80], mitogen activated protein kinase [77]. Although PKC has been postulated as a potential mechanism for IPC, it would seem more likely that PKC and other intracellular kinases play a key role in indiscriminately transferring the extracellular signal generated by IPC/RIPC to the cell nucleus.

\section{Nuclear Factor Kappa-Light-Chain-Enhancer of B Cells (NF- $\mathrm{kB}$ )}

$\mathrm{NF}-\mathrm{kB}$ is a transcription factor that is rapidly upregulated in ischaemic cells and has been shown to play a role in hepatic IR injury and to promote upregulation of iNOS and pro-inflammatory 
cytokines [75,81]. NF-kB levels were significantly upregulated within the first $4 \mathrm{~h}$ post IR injury in a murine model.

In mice that underwent IPC, NF-kB levels were significantly lower than those that did not [38]. This was associated with a reduction in TNF $\alpha$ mRNA levels. In porcine grafts undergoing IPC prior to cold storage, NF- $\mathrm{KB}$ translocation was upregulated early following IPC, prior to cold storage [27] suggesting that similar to PKC, NF- $\mathrm{KB}$ is more likely to be an intracellular messenger that is affected by extracellular molecules upregulated during IPC/RIPC.

\section{Haem-Oxygenase-1 (HO-1)}

Haem-oxygenase is an enzyme that catalyses the degradation of heme resulting in the production of anti-oxidant biliverdin and carbon monoxide [82] another gaseous signalling agent which has vasodilatory effects. Expression of HO-1 has been shown to be upregulated in hepatocytes following hepatic IR injury [28] and it has been shown to reduce hepatocyte apoptosis following IR injury, increase the availability of anti-oxidants, improve hepatic blood flow and to have anti-inflammatory effects [83] all of which have been suggested may ameliorate IR injury. Treatment of mice with gadolinium choride has been shown to upregulate HO-1 expression of Kupffer cells promoting an anti-inflammatory phenotype in Kupffer cells that was absent in HO-1 genetic knock out mice, and was associated with reduced liver injury [84]. Pharmacological upregulation of HO-1 with isoproterenol has been shown to reduce cytokine release from macrophage cell culture via down regulation of NF- $\mathrm{KB}$ following lipopolysaccharide stimulation and to reduce HMGB-1 release (a key driver of liver IR injury). This was associated with a significantly increased seven-day survival from 30 to $70 \%$ in a rat model of peritonitis [85]. Similar findings have been shown in a rat model of cardiac IR injury, in which again treatment with isoproterenol prior to occlusion of the left anterior descending artery for 30 min significantly increased circulating levels of HO-1 and HO-1 activity which was associated with significantly reduced levels of IL-6, TNF $\alpha$ and HMGB1 and significantly reduced infarct size [86]. Transduction experiments of rat livers with a viral vector for HO-1 injected into the portal vein prior to graft harvest have shown upregulation of HO-1 up to 90 days post transplantation and is associated with increased survival and immune tolerance [87] as demonstrated by an increased level of Tregs, Il-10 and TGF- $\beta$ in both the liver and the periphery.

RIPC of the hind limb has been shown to significantly upregulate HO-1 expression and activity on hepatocytes. This was measured after $4 \mathrm{~h}$ but prior to IR injury and was associated with a significant reduction in IR injury as measured by transaminases [28]. In contrast at $2 \mathrm{~h}$ post direct IPC and IR injury, although IR injury was ameliorated and HO-1 mRNA levels were upregulated, HO-1 was not detectable on hepatocytes, but was by $24 \mathrm{~h}$, suggesting that upregulation of HO- 1 takes several hours and may not be the earliest protective mechanism of IPC [29]. Interestingly, although HO-1 was upregulated on hepatocytes, there was no change identified in circulating lymphocytes [28]. The same group demonstrated in mice that HO-1 expression is upregulated following IR injury suggesting that the upregulation of HO-1 is necessary pre IR injury to be effective [30]. Upregulation of HO-1 in the liver following RIPC was seen to increase the incidence of autophagy [30]. This is the process by which cells envelop and degrade damaged cellular components within the cytoplasm preventing them from leaking in to the surrounding extracellular space where they act as damage associated molecular patterns (DAMPs) and may explain why RIPC can be associated with a reduction in HMGB1 release following IR injury [86].

\section{The Immune System}

IR injury is an example of sterile inflammation. Following reperfusion, the release of DAMPS into the extra cellular space provokes an intense inflammatory activation and several cell types have been implicated in this process. 


\section{CD4+ T Cells}

CD4+ T cells are a component of the lymphocyte populations and are rapidly recruited to post ischaemic tissue. There is clear evidence that CD4+ T cells play a key role in IR injury as mice lacking CD4+ T cells, although suffering a similar ischaemic injury, are protected from the reperfusion injury [74]. This phenomenon has not only been shown in the murine liver, but is evident in the murine kidney [88], and in the murine lung [89]. The CD4+ T cell population is composed of both pro inflammatory effector T cells and anti-inflammatory T cells. The effect of IPC on effector T cells has not been investigated as research has focused on the anti-inflammatory subgroup-regulatory $\mathrm{T}$ cells (Tregs). Three studies have looked at the effect of IPC on Treg recruitment and function, two in the kidney [31,32] and one in the liver [33]. The study protocols for the two studies in the kidney were very similar and IPC was performed seven days prior to the IR injury. Both studies demonstrated similar findings that not only did IPC ameliorate renal IR injury but also that Treg numbers in the ischaemic kidneys were upregulated. This upregulation of Tregs was not seen when the IR injury was performed three days or 14 days post IPC, suggesting that it is a delayed and transient phenomenon [31]. Treg function was measured by IL-10 production as measured by intracellular flow cytometry and this was significantly upregulated by IPC. Antibody depletion of Tregs by anti-CD25 antibody [32] or PC61 [31] ablated the protective effect of IPC. Furthermore adoptive transfer of Tregs obtained from mice that underwent IPC provided protection in naive mice [32]. In contrast, when IPC was performed immediately prior to IR injury, despite protection during IR injury, there was no evidence of Treg mobilization to the liver [33]. Furthermore depletion of Tregs did not ablate the protective effect of IPC and transfer of pre-activated Tregs into mice did not protect against IR injury and the authors came to the conclusion that the protection gained by IPC is independent of Tregs. The experiment they failed to perform was to augment Tregs into preconditioned mice and to add Tregs from preconditioned mice into naive mice. IPC has been shown to result in a reduction in circulating cytokines especially IL-6 which is known to act as a brake of Treg activation, proliferation and function [90] and to promote CD4+ effector T cell migration [91]. It is most likely that key factor in the differences between these studies is the timing between the preconditioning stimulus and IR injury. It is perhaps unrealistic to expect IPC to have a profound effect of T cells populations within such a short period of time. However, IPC/RIPC is more likely to alter the cytokine milieu that may affect early T cell responses and direct the later $\mathrm{T}$ cell response.

\section{Macrophages}

Kupffer Cells are resident liver macrophages and have been shown to be activated early following IR injury $[92,93]$. However experiments blocking macrophage activity have had varied results with some studies demonstrating that Kupffer cell blockade or modulation attenuated IR injury [94,95] whilst other models have shown increased IR injury following Kupffer cell depletion [96].

IPC has been shown to reduce Kupffer cell activation following IR injury as measured by reduced phagocytosis of latex particles [36] reduced reactive oxygen species secretion [34] and reduced TNF $\alpha$ secretion leading not only to reduced hepatic IR injury [34] but also reduced neutrophil accumulation in distant end organs [35]. However, arguably the most important study is a study from Tejima and colleagues in which the results suggest that IPC directly reduced hepatocycyte injury and death rather than through suppressing Kupffer cell activation [37]. Interestingly though they found in the absence of Kupffer cells, this protection was not gained suggesting a key role for macrophages in the preconditioning stimulus. This is in keeping with the theory that IPC/RIPC works by causing limited tissue injury resulting in protective mechanisms being activated.

\section{Monocytes}

Inflammatory monocytes are rapidly recruited to sites of tissue injury from the bone marrow by chemokine ligand 2 (CCL2) [97]. Few studies have looked at the role of inflammatory monocytes in 
hepatic IR injury, however they have been shown to play a key role in acetaminophen liver injury in small animal models [98]. One study using genetic CCL2 knock out mice has demonstrated that these are protected from hepatic IR injury leading to the suggestion that inflammatory monocytes play a key role in the pathogenesis of IR injury [99]. No studies have investigated the effect of IPC/RIPC on inflammatory monocytes.

\section{Cytokines}

Hepatic IR injury is associated with the early release of several pro-inflammatory cytokines. IL-2 [100], IL-6 [100,101], IL-17 [102], and TNF $\alpha$ [100,101] have been shown to be upregulated following hepatic IR injury and to be associated with increased hepatocyte apoptosis and neutrophil infiltration into the post ischaemic liver. TNF $\alpha$ is a key pro inflammatory cytokine that has been shown to play a role in hepatic IR injury and treatment of mice with anti-TNF $\alpha$ prior to IR injury is associated with a significant reduction in injury [100].

Serum cytokines have been measured in many small animal models of IPC/RIPC and there is strong evidence to show that IPC and RIPC are associated with a reduction in TNF $\alpha$ production in the liver in the first few hours following reperfusion [39,43]. Pre-treatment of mice undergoing IPC with DPCPX, an $\mathrm{A}_{1} \mathrm{R}$ antagonist abolished the protective effect of IPC and the reduction in serum $\mathrm{TNF} \alpha$ levels suggesting that adenosine signalling may dampen down the immune response [19]. Furthermore, inhibition of NF- $\mathrm{KB}$ translocation by IPC led to a reduction TNF $\alpha$ mRNA in murine livers following IR injury [38].

IL-6 levels have similarly been shown to be reduced in the early hours post IR injury in mice undergoing IPC [40,42]. However, IPC is associated with a spike in IL-6 levels within the first hour post IR injury [42]. Although no studies of IPC/RIPC in hepatic IR injury have been performed in either IL-6 or TNF $\alpha$ deficient mice, studies have suggested that both IL- 6 and TNF $\alpha$ are essential for hepatic regeneration and studies of hepatectomy in IL-6 deficient mice have demonstrated a more significant IR injury with increased mortality $[40,103,104]$. It should be noted that this model purposefully used a small for size liver remnant and several studies have shown that IPC is protective in normal livers. Similar results have been seen with TNF receptor deficient mice [105]. This may be explained by the fact that some immune cells have been shown to be pleiotropic and inflammatory monocytes recruited to sites of sterile inflammation in the liver were seen to phenotypically change and become alternative monocytes which are essential to tissue regeneration [106].

There has been much interest in IL-10, a potent anti-inflammatory cytokine both in terms of whether its supplementation may ameliorate IR injury and whether it is upregulated by IPC/RIPC. Treatment of mice with recombinant IL-10 prior to IR injury significantly attenuated IR injury and interestingly was associated with a reduction in TNF $\alpha$ production in the liver [105]. IL-10 depletion has been shown to result in increased liver injury and increased production of TNF $\alpha$ and IL-6 (89) [95] again demonstrating an interplay between these pro-inflammatory and anti-inflammatory cytokines and suggesting that manipulating cytokine production could alter IR injury. The effect of IPC on IL-10 levels post IR injury have been conflicting. In a rodent model, of direct RIPC, although IR injury was attenuated, IL-10 levels were not upregulated [42]. In contrast, in a trial of donor IPC in human liver transplantation, recipients that received a liver that underwent IPC prior to retrieval has significantly higher serum levels of Il-10 at three hours post reperfusion [41]. This was not associated with a reduction in IR injury but was associated with a significant reduction in both moderate and severe acute rejection episodes.

Although IL-6, IL-10 and TNF $\alpha$ knockout mice do exist as do neutralizing antibodies, these experiment have not to our knowledge been performed and as such, although IPC has been shown to alter levels of these cytokines, it remains unknown as to whether this is necessary for the protection garnered by IPC or as a consequence of IPC reducing hepatocyte death. 


\section{Conclusions}

IPC/RIPC are an inexpensive and easily applied mechanism depending on intrinsic survival responses for protection during IR injury. Despite being first described in 1986 [4] and 1996 [5], the mechanisms by which they provide protection remain unclear and this has hampered their clinical translation. The release of adenosine from the ischaemic tissue during the preconditioning stimulus would appear to be the earliest and potentially the initial mechanism for signalling protection. Work from Peralta and colleagues [16] demonstrates that the optimal length of the preconditioning stimulus requires a delicate balance between being long enough to release sufficient quantities of adenosine but not too long that it simultaneously releases toxic metabolites. No studies have been done to date in humans to investigate the optimal time required for the preconditioning stimulus however studies measuring adenosine release in the organ undergoing the preconditioning stimulus may shed light on this. Following adenosine release and stimulation of the various adenosine receptors, there is evidence of decreased apoptosis and enhanced autophagy reducing release of DAMPS. Intracellular signalling via protein kinases and NF- $\mathrm{kB}$ leads to upregulation of pro survival pathways including HO-1. ENOS is upregulated along with L-arginine levels and the resulting NO produced has been shown to improve hepatic microcirculation and reduce the reperfusion injury. It is difficult to identify the predominant method of protection in these small animal studies as each study has only investigated one pathway and blockade/genetic knockdown of that pathway has abrogated the protective effect of IPC/RIPC. In humans, the picture is more complicated by the interplay of all of the pathways and the effect of chronic disease on these pathways. The next key step is to measure how long the IPC/RIPC stimulus requires to be applied in humans to release adequate adenosine/L-arginine as this may allow IPC/RIPC to be more successfully translated to clinical practice.

Acknowledgments: We gratefully acknowledge the Wellington Hospital, London/HCA for the fellowship for Francis Robertson.

Author Contributions: F.R. performed the literature search and wrote the manuscript. B.F. and B.D. contributed to writing the manuscript and reviewed the final draft.

Conflicts of Interest: The authors declare no conflict of interest

\section{References}

1. Veteläinen, R.; van Vliet, A.; Gouma, D.J.; van Gulik, T.M. Steatosis as a risk factor in liver surgery. Ann. Surg. 2007, 245, 20-30. [CrossRef] [PubMed]

2. Selzner, M.; Clavien, P.-A. Fatty liver in liver transplantation and surgery. Semin. Liver Dis. 2001, 21, 105-113. [CrossRef] [PubMed]

3. Callaghan, C.J.; Charman, S.C.; Muiesan, P.; Powell, J.J.; Gimson, A.E.; van der Meulen, J.H.P. Outcomes of transplantation of livers from donation after circulatory death donors in the UK: A cohort study. BMJ Open 2013, 3, e003287. [CrossRef] [PubMed]

4. Murry, C.E.; Jennings, R.B.; Reimer, K.A. Preconditioning with ischemia: A delay of lethal cell injury in ischemic myocardium. Circulation 1986, 74, 1124-1136. [CrossRef] [PubMed]

5. Przyklenk, K.; Bauer, B.; Ovize, M.; Kloner, R.A.; Whittaker, P. Regional ischemic “preconditioning” protects remote virgin myocardium from subsequent sustained coronary occlusion. Circulation 1993, 87, 893-899. [CrossRef] [PubMed]

6. Clavien, P.A.; Yadav, S.; Sindram, D.; Bentley, R.C. Protective effects of ischemic preconditioning for liver resection performed under inflow occlusion in humans. Ann. Surg. 2000, 232, 155-162. [CrossRef] [PubMed]

7. Clavien, P.-A.; Selzner, M.; Rüdiger, H.A.; Graf, R.; Kadry, Z.; Rousson, V.; Jochum, W. A prospective randomized study in 100 consecutive patients undergoing major liver resection with versus without ischemic preconditioning. Ann. Surg. 2003, 238, 843-852. [CrossRef] [PubMed]

8. Kanoria, S.; Robertson, F.P.; Mehta, N.N.; Fusai, G.; Sharma, D.; Davidson, B.R. Effect of Remote Ischaemic Preconditioning on Liver Injury in Patients Undergoing Major Hepatectomy for Colorectal Liver Metastasis: A Pilot Randomised Controlled Feasibility Trial. World J. Surg. 2016. [CrossRef] [PubMed] 
9. O'Neill, S.; Leuschner, S.; McNally, S.J.; Garden, O.J.; Wigmore, S.J.; Harrison, E.M. Meta-analysis of ischaemic preconditioning for liver resections. Br. J. Surg. 2013, 100, 1689-1700. [CrossRef] [PubMed]

10. Robertson, F.P.; Magill, L.J.; Wright, G.P.; Fuller, B.; Davidson, B.R. A systematic review and meta-analysis of donor ischaemic preconditioning in liver transplantation. Transpl. Int. 2016. [CrossRef] [PubMed]

11. McCafferty, K.; Forbes, S.; Thiemermann, C.; Yaqoob, M.M. The challenge of translating ischemic conditioning from animal models to humans: The role of comorbidities. Dis. Model. Mech. 2014, 7, 1321-1333. [CrossRef] [PubMed]

12. Hausenloy, D.J.; Candilio, L.; Evans, R.; Ariti, C.; Jenkins, D.P.; Kolvekar, S.; Knight, R.; Kunst, G.; Laing, C.; Nicholas, J.; et al. Remote Ischemic Preconditioning and Outcomes of Cardiac Surgery. N. Engl. J. Med. 2015, 373, 1408-1417. [CrossRef] [PubMed]

13. Meybohm, P.; Bein, B.; Brosteanu, O.; Cremer, J.; Gruenewald, M.; Stoppe, C.; Coburn, M.; Schaelte, G.; Böning, A.; Niemann, B.; et al. A Multicenter Trial of Remote Ischemic Preconditioning for Heart Surgery. N. Engl. J. Med. 2015, 373, 1397-1407. [CrossRef] [PubMed]

14. Robertson, F.P.; Goswami, R.; Wright, G.P.; Imber, C.; Sharma, D.; Malago, M.; Fuller, B.J.; Davidson, B.R. Remote ischaemic preconditioning in orthotopic liver transplantation (RIPCOLT trial): A pilot randomized controlled feasibility study. HPB 2017. [CrossRef] [PubMed]

15. Peralta, C.; Hotter, G.; Closa, D.; Gelpí, E.; Bulbena, O.; Rosello-Catafau, J. Protective effect of preconditioning on the injury associated to hepatic ischemia-reperfusion in the rat: Role of nitric oxide and adenosine. Hepatology 1997, 25, 934-937. [CrossRef] [PubMed]

16. Peralta, C.; Closa, D.; Xaus, C.; Gelpí, E.; Roselló-catafau, J.; Hotter, G. Hepatic preconditioning in rats is defined by a balance of adenosine and xanthine. Hepatology 1998, 28, 768-773. [CrossRef] [PubMed]

17. Nakayama, H.; Yamamoto, Y.; Kume, M.; Yamagami, K.; Yamamoto, H.; Kimoto, S.; Ishikawa, Y.; Ozaki, N.; Shimahara, Y.; Yamaoka, Y. Pharmacologic stimulation of adenosine A2 receptor supplants ischemic preconditioning in providing ischemic tolerance in rat livers. Surgery 1999, 126, 945-954. [CrossRef]

18. Peralta, C.; Hotter, G.; Closa, D.; Prats, N.; Xaus, C.; Gelpí, E.; Roselló-Catafau, J. The protective role of adenosine in inducing nitric oxide synthesis in rat liver ischemia preconditioning is mediated by activation of adenosine $\mathrm{A}_{2}$ receptors. Hepatology 1999, 29, 126-132. [CrossRef] [PubMed]

19. Ajamieh, H.H.; Candelario-Jalil, E.; Fernández, O.S.L.; Gerbes, A.L. Ischaemic and pharmacological preconditionings protect liver via adenosine and redox status following hepatic ischaemia/reperfusion in rats. Clin. Sci. 2008, 115, 69-77. [CrossRef] [PubMed]

20. Schauer, R.; Gerbes, A.L.; Vonier, D.; op den Winkel, M.; Fraunberger, P.; Bilzer, M. Induction of cellular resistance against Kupffer cell-derived oxidant stress: A novel concept of hepatoprotection by ischemic preconditioning. Hepatology 2003, 37, 286-295. [CrossRef] [PubMed]

21. Chouker, A.; Ohta, A.; Martignoni, A.; Lukashev, D.; Zacharia, L.C.; Jackson, E.K.; Schnermann, J.; Ward, J.M.; Kaufmann, I.; Klaunberg, B.; et al. In Vivo Hypoxic Preconditioning Protects From Warm Liver Ischemia-Reperfusion Injury Through the Adenosine A2B Receptor. Transplantation 2012, 94, 894-902. [CrossRef] [PubMed]

22. Koti, R.S.; Tsui, J.; Lobos, E.; Yang, W.; Seifalian, A.M.; Davidson, B.R. Nitric oxide synthase distribution and expression with ischemic preconditioning of the rat liver. FASEB J. 2005, 19, 1155-1157. [CrossRef] [PubMed]

23. Abu-Amara, M.; Yang, S.Y.; Quaglia, A.; Rowley, P.; Fuller, B.; Seifalian, A.; Davidson, B. Role of endothelial nitric oxide synthase in remote ischemic preconditioning of the mouse liver. Liver Transpl. 2011, 17, 610-619. [CrossRef] [PubMed]

24. Carini, R.; De Cesaris, M.G.; Splendore, R.; Bagnati, M.; Albano, E. Ischemic preconditioning reduces Na+ accumulation and cell killing in isolated rat hepatocytes exposed to hypoxia. Hepatology 2000, 31, 166-172. [CrossRef] [PubMed]

25. Carini, R.; De Cesaris, M.G.; Splendore, R.; Vay, D.; Domenicotti, C.; Nitti, M.P.; Paola, D.; Pronzato, M.A.; Albano, E. Signal pathway involved in the development of hypoxic preconditioning in rat hepatocytes. Hepatology 2001, 33, 131-139. [CrossRef] [PubMed]

26. Ricciardi, R.; Meyers, W.C.; Schaffer, B.K.; Kim, R.D.; Shah, S.A.; Wheeler, S.M.; Donohue, S.E.; Sheth, K.R.; Callery, M.P.; Chari, R.S. Protein kinase C inhibition abrogates hepatic ischemic preconditioning responses. J. Surg. Res. 2001, 97, 144-149. [CrossRef] [PubMed]

27. Ricciardi, R.; Shah, S.A.; Wheeler, S.M.; Quarfordt, S.H.; Callery, M.P.; Meyers, W.C.; Chari, R.S. Regulation of NFKB in hepatic ischemic preconditioning. J. Am. Coll. Surg. 2002, 195, 319-326. [CrossRef] 
28. Lai, I.-R.; Chang, K.-J.; Chen, C.-F.; Tsai, H.-W. Transient limb ischemia induces remote preconditioning in liver among rats: The protective role of heme oxygenase-1. Transplantation 2006, 81, 1311-1317. [CrossRef] [PubMed]

29. Datta, G.; Luong, T.V.; Fuller, B.J.; Davidson, B.R. Endothelial nitric oxide synthase and heme oxygenase-1 act independently in liver ischemic preconditioning. J. Surg. Res. 2014, 186, 417-428. [CrossRef] [PubMed]

30. Wang, Y.; Shen, J.; Xiong, X.; Xu, Y.; Zhang, H.; Huang, C.; Tian, Y.; Jiao, C.; Wang, X.; Li, X. Remote ischemic preconditioning protects against liver ischemia-reperfusion injury via heme oxygenase-1-induced autophagy. PLOS ONE 2014, 9, e98834. [CrossRef] [PubMed]

31. Kinsey, G.R.; Huang, L.; Vergis, A.L.; Li, L.; Okusa, M.D. Regulatory T cells contribute to the protective effect of ischemic preconditioning in the kidney. Kidney Int. 2010, 77, 771-780. [CrossRef] [PubMed]

32. Cho, W.Y.; Choi, H.M.; Lee, S.Y.; Kim, M.G.; Kim, H.-K.; Jo, S.-K. The role of Tregs and CD11c(+) macrophages/dendritic cells in ischemic preconditioning of the kidney. Kidney Int. 2010, 78, 981-992. [CrossRef] [PubMed]

33. Devey, L.R.; Richards, J.A.; O'Connor, R.A.; Borthwick, G.; Clay, S.; Howie, A.F.; Wigmore, S.J.; Anderton, S.M.; Howie, S.E.M. Ischemic preconditioning in the liver is independent of regulatory T cell activity. PLoS ONE 2012, 7, e49647. [CrossRef] [PubMed]

34. Peralta, C.; Prats, N.; Xaus, C.; Gelpí, E.; Roselló-Catafau, J. Protective effect of liver ischemic preconditioning on liver and lung injury induced by hepatic ischemia-reperfusion in the rat. Hepatology 1999, 30, 1481-1489. [CrossRef] [PubMed]

35. Peralta, C.; Fernández, L.; Panés, J.; Prats, N.; Sans, M.; Piqué, J.M.; Gelpí, E.; Roselló-Catafau, J.; Roselló-Catafau, J. Preconditioning protects against systemic disorders associated with hepatic ischemia-reperfusion through blockade of tumor necrosis factor-induced P-selectin up-regulation in the rat. Hepatology 2001, 33, 100-113. [CrossRef] [PubMed]

36. Glanemann, M.; Vollmar, B.; Nussler, A.K.; Schaefer, T.; Neuhaus, P.; Menger, M.D. Ischemic preconditioning protects from hepatic ischemia/reperfusion-injury by preservation of microcirculation and mitochondrial redox-state. J. Hepatol. 2003, 38, 59-66. [CrossRef]

37. Arai, M.; Ikeda, H.; Tomiya, T.; Yanase, M.; Inoue, Y.; Nagashima, K.; Nishikawa, T.; Watanabe, N.; Omata, M.; Fujiwara, K.; et al. Ischemic preconditioning protects hepatocytes via reactive oxygen species derived from Kupffer cells in rats. Gastroenterology 2004, 127, 1488-1496. [CrossRef]

38. Funaki, H.; Shimizu, K.; Harada, S.-I.; Tsuyama, H.; Fushida, S.; Tani, T.; Miwa, K. Essential role for nuclear factor kappaB in ischemic preconditioning for ischemia-reperfusion injury of the mouse liver. Transplantation 2002, 74, 551-556. [CrossRef] [PubMed]

39. Zhang, S.-J.; Zhu, C.-J.; Zhao, Y.-F.; Li, J.; Guo, W.-Z. Different ischemic preconditioning for rat liver graft: Protection and mechanism. Hepatobiliary Pancreat. Dis. Int. 2003, 2, 509-512. [PubMed]

40. Yao, A.; Li, X.; Pu, L.; Zhong, J.; Liu, X.; Yu, Y.; Zhang, F.; Kong, L.; Sun, B.; Wang, X.; et al. Impaired hepatic regeneration by ischemic preconditioning in a rat model of small-for-size liver transplantation. Transpl. Immunol. 2007, 18, 37-43. [CrossRef] [PubMed]

41. Koneru, B.; Shareef, A.; Dikdan, G.; Desai, K.; Klein, K.M.; Peng, B.; Wachsberg, R.H.; de la Torre, A.N.; Debroy, M.; Fisher, A.; et al. The ischemic preconditioning paradox in deceased donor liver transplantation-Evidence from a prospective randomized single blind clinical trial. Am. J. Transplant. 2007, 7, 2788-2796. [CrossRef] [PubMed]

42. Guimarães Filho, M.A.C.; Cortez, E.; Garcia-Souza, É.P.; Soares, V.M.; Moura, A.S.; Carvalho, L.; Maya, M.C.A.; Pitombo, M.B. Effect of remote ischemic preconditioning in the expression of IL-6 and IL-10 in a rat model of liver ischemia-reperfusion injury. Acta Cir. Bras. 2015, 30, 452-460. [CrossRef] [PubMed]

43. Li, D.-Y.; Shi, X.-J.; Li, W.; Sun, X.-D.; Wang, G.-Y. Ischemic preconditioning and remote ischemic preconditioning provide combined protective effect against ischemia/reperfusion injury. Life Sci. 2016, 150, 76-80. [CrossRef] [PubMed]

44. Hausenloy, D.; Yellon, D.M. New directions for protecting the heart against ischaemia-reperfusion injury: Targeting the Reperfusion Injury Salvage Kinase (RISK)-pathway. Cardiovasc. Res. 2004, 61, 448-460. [CrossRef] [PubMed] 
45. Marber, M.S.; Latchman, D.S.; Walker, J.M.; Yellon, D.M. Cardiac stress protein elevation 24 hours after brief ischemia or heat stress is associated with resistance to myocardial infarction. Circulation 1993, 88, 1264-1272. [CrossRef] [PubMed]

46. Kuzuya, T.; Hoshida, S.; Yamashita, N.; Fuji, H.; Oe, H.; Hori, M.; Kamada, T.; Tada, M. Delayed effects of sublethal ischemia on the acquisition of tolerance to ischemia. Circ. Res. 1993, 72, 1293-1299. [CrossRef] [PubMed]

47. Hausenloy, D.J.; Yellon, D.M. The second window of preconditioning (SWOP) where are we now? Cardiovasc. Drugs Ther. 2010, 24, 235-254. [CrossRef] [PubMed]

48. Lim, S.Y.; Hausenloy, D.J. Remote ischemic conditioning: From bench to bedside. Front. Physiol. $2012,3,27$. [CrossRef] [PubMed]

49. Fredholm, B.B. Adenosine, an endogenous distress signal, modulates tissue damage and repair. Cell Death Differ. 2007, 14, 1315-1323. [CrossRef] [PubMed]

50. Fredholm, B.B.; IJzerman, A.P.; Jacobson, K.A.; Klotz, K.N.; Linden, J. International Union of Pharmacology. XXV. Nomenclature and classification of adenosine receptors. Pharmacol. Rev. 2001, 53, 527-552. [PubMed]

51. Laubach, V.E.; French, B.A.; Okusa, M.D. Targeting of adenosine receptors in ischemia-reperfusion injury. Expert Opin. Ther. Targets 2011, 15, 103-118. [CrossRef] [PubMed]

52. Todo, S.; Zhu, Y.; Zhang, S.; Jin, M.B.; Ishizaki, N.; Tanaka, H.; Subbotin, V.; Starzl, T.E. Attenuation of ischemic liver injury by augmentation of endogenous adenosine. Transplantation 1997, 63, 217-223. [CrossRef] [PubMed]

53. Li, J.M.; Fenton, R.A.; Cutler, B.S.; Dobson, J.G. Adenosine enhances nitric oxide production by vascular endothelial cells. Am. J. Physiol. 1995, 269, C519-C523. [PubMed]

54. Koneru, B.; Fisher, A.; He, Y.; Klein, K.M.; Skurnick, J.; Wilson, D.J.; de la Torre, D.N.; Merchant, A.; Arora, R.; Samanta, A.K.; et al. Ischemic preconditioning in deceased donor liver transplantation: A prospective randomized clinical trial of safety and efficacy. Liver Transplant. 2005, 11, 196-202. [CrossRef] [PubMed]

55. Jassem, W.; Fuggle, S.V.; Cerundolo, L.; Heaton, N.D.; Rela, M. Ischemic preconditioning of cadaver donor livers protects allografts following transplantation. Transplantation 2006, 81, 169-174. [CrossRef] [PubMed]

56. Kim, J.; Kim, M.; Song, J.H.; Lee, H.T. Endogenous A1 adenosine receptors protect against hepatic ischemia reperfusion injury in mice. Liver Transplant. 2008, 14, 845-854. [CrossRef] [PubMed]

57. Magata, S.; Taniguchi, M.; Suzuki, T.; Shimamura, T.; Fukai, M.; Furukawa, H.; Fujita, M.; Todo, S. The Effect of Antagonism of Adenosine A1 Receptor Against Ischemia and Reperfusion Injury of the Liver. J. Surg. Res. 2007, 139, 7-14. [CrossRef] [PubMed]

58. Ben-Ari, Z.; Pappo, O.; Sulkes, J.; Cheporko, Y.; Vidne, B.A.; Hochhauser, E. Effect of adenosine A2A receptor agonist (CGS) on ischemia/reperfusion injury in isolated rat liver. Apoptosis 2005, 10, 955-962. [CrossRef] [PubMed]

59. Thurman, R.G.; Lemasters, J.J.; Arai, M.; Thurman, R.G.; Lemasters, J.J. Contribution of adenosine A(2) receptors and cyclic adenosine monophosphate to protective ischemic preconditioning of sinusoidal endothelial cells against Storage/Reperfusion injury in rat livers. Hepatology 2000, 32, 297-302. [CrossRef]

60. Day, Y.-J.; Marshall, M.A.; Huang, L.; McDuffie, M.J.; Okusa, M.D.; Linden, J. Protection from ischemic liver injury by activation of A2A adenosine receptors during reperfusion: inhibition of chemokine induction. AJP Gastrointest. Liver Physiol. 2004, 286, G285-G293. [CrossRef] [PubMed]

61. Lappas, C.M.; Day, Y.-J.; Marshall, M.A.; Engelhard, V.H.; Linden, J. Adenosine A2A receptor activation reduces hepatic ischemia reperfusion injury by inhibiting CD1d-dependent NKT cell activation. J. Exp. Med. 2006, 203, 2639-2648. [CrossRef] [PubMed]

62. Zimmerman, M.A.; Grenz, A.; Tak, E.; Kaplan, M.; Ridyard, D.; Brodsky, K.S.; Mandell, M.S.; Kam, I.; Eltzschig, H.K. Signaling through hepatocellular A2B adenosine receptors dampens ischemia and reperfusion injury of the liver. Proc. Natl. Acad. Sci. USA 2013, 110, 12012-12017. [CrossRef] [PubMed]

63. Abu-Amara, M.; Yang, S.Y.; Seifalian, A.; Davidson, B.; Fuller, B. The nitric oxide pathway-Evidence and mechanisms for protection against liver ischaemia reperfusion injury. Liver Int. 2012, 32, 531-543. [CrossRef] [PubMed]

64. Abu-Amara, M.; Yang, S.Y.; Quaglia, A.; Rowley, P.; Tapuria, N.; Seifalian, A.M.; Fuller, B.J.; Davidson, B.R. Effect of remote ischemic preconditioning on liver ischemia/reperfusion injury using a new mouse model. Liver Transpl. 2011, 17, 70-82. [CrossRef] [PubMed] 
65. Peralta, C.; Rull, R.; Rimola, A.; Deulofeu, R.; Roselló-Catafau, J.; Gelpí, E.; Rodés, J. Endogenous nitric oxide and exogenous nitric oxide supplementation in hepatic ischemia-reperfusion injury in the rat. Transplantation 2001, 71, 529-536. [CrossRef] [PubMed]

66. Hines, I.N.; Kawachi, S.; Harada, H.; Pavlick, K.P.; Hoffman, J.M.; Bharwani, S.; Wolf, R.E.; Grisham, M.B. Role of nitric oxide in liver ischemia and reperfusion injury. Mol. Cell. Biochem. 2002, 234, 229-237. [CrossRef] [PubMed]

67. Hines, I.N.; Harada, H.; Flores, S.; Gao, B.; McCord, J.M.; Grisham, M.B. Endothelial nitric oxide synthase protects the post-ischemic liver: potential interactions with superoxide. Biomed. Pharmacother. 2005, 59, 183-189. [CrossRef] [PubMed]

68. Kawachi, S.; Hines, I.N.; Laroux, F.S.; Hoffman, J.; Bharwani, S.; Gray, L.; Leffer, D.; Grisham, M.B. Nitric Oxide Synthase and Postischemic Liver Injury. Biochem. Biophys. Res. Commun. 2000, 276, 851-854. [CrossRef] [PubMed]

69. Lee, V.G.; Johnson, M.L.; Baust, J.; Laubach, V.E.; Watkins, S.C.; Billiar, T.R. The roles of iNOS in liver ischemia-reperfusion injury. Shock 2001, 16, 355-360. [CrossRef] [PubMed]

70. Theruvath, T.P.; Zhong, Z.; Currin, R.T.; Ramshesh, V.K.; Lemasters, J.J. Endothelial nitric oxide synthase protects transplanted mouse livers against storage/reperfusion injury: Role of vasodilatory and innate immunity pathways. Transplant. Proc. 2006, 38, 3351-3357. [CrossRef] [PubMed]

71. Duranski, M.R.; Elrod, J.W.; Calvert, J.W.; Bryan, N.S.; Feelisch, M.; Lefer, D.J. Genetic overexpression of eNOS attenuates hepatic ischemia-reperfusion injury. AJP Hear. Circ. Physiol. 2006, 291, H2980-H2986. [CrossRef] [PubMed]

72. Serracino-Inglott, F.; Virlos, I.T.; Habib, N.A.; Williamson, R.C.N.; Mathie, R.T. Adenosine preconditioning attenuates hepatic reperfusion injury in the rat by preventing the down-regulation of endothelial nitric oxide synthase. BMC Gastroenterol. 2002, 2, 22. [CrossRef]

73. Wang, L.-M.; Tian, X.-F.; Song, Q.-Y.; Gao, Z.-M.; Luo, F.-W.; Yang, C.-M. Expression and role of inducible nitric oxide synthase in ischemia-reperfusion liver in rats. Hepatobiliary Pancreat. Dis. Int. 2003, 2, $252-258$. [PubMed]

74. Zwacka, R.M.; Zhang, Y.; Halldorson, J.; Schlossberg, H.; Dudus, L.; Engelhardt, J.F. CD4(+) T-lymphocytes mediate ischemia/reperfusion-induced inflammatory responses in mouse liver. J. Clin. Investig. 1997, 100, 279-289. [CrossRef] [PubMed]

75. Bradham, C.A.; Stachlewitz, R.F.; Gao, W.; Qian, T.; Jayadev, S.; Jenkins, G.; Hannun, Y.; Lemasters, J.J.; Thurman, R.G.; Brenner, D.A. Reperfusion after liver transplantation in rats differentially activates the mitogen-activated protein kinases. Hepatology 1997, 25, 1128-1135. [CrossRef] [PubMed]

76. Nakano, A.; Cohen, M.V.; Downey, J.M. Ischemic preconditioning: from basic mechanisms to clinical applications. Pharmacol. Ther. 2000, 86, 263-275. [CrossRef]

77. Carini, R.; Grazia De Cesaris, M.; Splendore, R.; Domenicotti, C.; Nitti, M.P.; Pronzato, M.A.; Albano, E. Signal pathway responsible for hepatocyte preconditioning by nitric oxide. Free Radic. Biol. Med. 2003, 34, 1047-1055. [CrossRef]

78. Yamaguchi, K.; Kawahara, T.; Kumakura, S.; Hua, J.; Kugimiya, T.; Nagaoka, I.; Inada, E. Effect of olprinone, a phosphodiesterase iii inhibitor, on hepatic ischemia-reperfusion injury in rats. Shock 2010, 33, 436-441. [CrossRef] [PubMed]

79. Meng, G.-X.; Yuan, Q.; Wei, L.-P.; Meng, H.; Wang, Y.-J. Protein kinase C- $\beta$ inhibitor treatment attenuates hepatic ischemia and reperfusion injury in diabetic rats. Exp. Ther. Med. 2016, 11, 565-570. [CrossRef] [PubMed]

80. Ricciardi, R.; Schaffer, B.K.; Kim, R.D.; Shah, S.A.; Donohue, S.E.; Wheeler, S.M.; Quarfordt, S.H.; Callery, M.P.; Meyers, W.C.; Chari, R.S.; et al. Protective effects of ischemic preconditioning on the cold-preserved liver are tyrosine kinase dependent. Transplantation 2001, 72, 406-412. [CrossRef] [PubMed]

81. Hur, G.M.; Ryu, Y.S.; Yun, H.Y.; Jeon, B.H.; Kim, Y.M.; Seok, J.H.; Lee, J.H. Hepatic Ischemia/Reperfusion in Rats Induces iNOS Gene Transcription by Activation of NF-kB. Biochem. Biophys. Res. Commun. 1999, 261, 917-922. [CrossRef] [PubMed]

82. Choi, A.M.K.; Alam, J. Heme Oxygenase-1: Function, Regulation, and Implication of a Novel Stress-inducible Protein in Oxidant-induced Lung Injury. Am. J. Respir. Cell Mol. Biol. 1996, 15, 9-19. [CrossRef] [PubMed]

83. Origassa, C.S.T.; Câmara, N.O.S. Cytoprotective role of heme oxygenase-1 and heme degradation derived end products in liver injury. World J. Hepatol. 2013, 5, 541-549. [PubMed] 
84. Devey, L.; Ferenbach, D.; Mohr, E.; Sangster, K.; Bellamy, C.O.; Hughes, J.; Wigmore, S.J. Tissue-resident macrophages protect the liver from ischemia reperfusion injury via a heme oxygenase-1-dependent mechanism. Mol. Ther. 2009, 17, 65-72. [CrossRef] [PubMed]

85. Ha, Y.M.; Ham, S.A.; Kim, Y.M.; Lee, Y.S.; Kim, H.J.; Seo, H.G.; Lee, J.H.; Park, M.K.; Chang, K.C. $\beta 1$-Adrenergic receptor-mediated HO-1 induction, via PI3K and p38 MAPK, by isoproterenol in RAW 264.7 cells leads to inhibition of HMGB1 release in LPS-activated RAW 264.7 cells and increases in survival rate of CLP-induced septic mice. Biochem. Pharmacol. 2011, 82, 769-777. [CrossRef] [PubMed]

86. Wang, J.; Hu, X.; Fu, W.; Xie, J.; Zhou, X.; Jiang, H. Isoproterenol-mediated heme oxygenase-1 induction inhibits high mobility group box 1 protein release and protects against rat myocardial ischemia/reperfusion injury in vivo. Mol. Med. Rep. 2014. [CrossRef] [PubMed]

87. Sun, L.; Shi, T.; Qiao, H.; Jiang, X.; Jiang, H.; Krissansen, G.W.; Sun, X. Hepatic Overexpression of Heme Oxygenase-1 Improves Liver Allograft Survival by Expanding T Regulatory Cells. J. Surg. Res. 2011, 166, e187-e194. [CrossRef] [PubMed]

88. Burne, M.J.; Daniels, F.; El Ghandour, A.; Mauiyyedi, S.; Colvin, R.B.; O’Donnell, M.P.; Rabb, H. Identification of the CD4(+) T cell as a major pathogenic factor in ischemic acute renal failure. J. Clin. Investig. 2001, 108, 1283-1290. [CrossRef] [PubMed]

89. Yang, Z.; Sharma, A.K.; Linden, J.; Kron, I.L.; Laubach, V.E. CD4+ T lymphocytes mediate acute pulmonary ischemia-reperfusion injury. J. Thorac. Cardiovasc. Surg. 2009, 137, 695-702. [CrossRef] [PubMed]

90. Dienz, O.; Rincon, M. The effects of IL-6 on CD4 T cell responses. Clin. Immunol. 2009, 130, 27-33. [CrossRef] [PubMed]

91. Nish, S.A.; Schenten, D.; Wunderlich, F.T.; Pope, S.D.; Gao, Y.; Hoshi, N.; Yu, S.; Yan, X.; Lee, H.K.; Pasman, L.; et al. T cell-intrinsic role of IL-6 signaling in primary and memory responses. Elife 2014, 3, e01949. [CrossRef] [PubMed]

92. Caldwell-Kenkel, J.C.; Currin, R.T.; Tanaka, Y.; Thurman, R.G.; Lemasters, J.J. Kupffer cell activation and endothelial cell damage after storage of rat livers: effects of reperfusion. Hepatology 1991, 13, 83-95. [PubMed]

93. Shiratori, Y.; Kiriyama, H.; Fukushi, Y.; Nagura, T.; Takada, H.; Hai, K.; Kamii, K. Modulation of ischemia-reperfusion-induced hepatic injury by Kupffer cells. Dig. Dis. Sci. 1994, 39, 1265-1272. [CrossRef] [PubMed]

94. Bailey, S.M.; Reinke, L.A. Antioxidants and gadolinium chloride attenuate hepatic parenchymal and endothelial cell injury induced by low flow ischemia and reperfusion in perfused rat livers. Free Radic. Res. 2000, 32, 497-506. [CrossRef] [PubMed]

95. Liang, J.; Yamaguchi, Y.; Matsumura, F.; Goto, M.; Akizuki, E.; Matsuda, T.; Okabe, K.; Ohshiro, H.; Ishihara, K.; Yamada, S.; et al. Calcium-Channel Blocker Attenuates Kupffer Cell Production of Cytokine-Induced Neutrophil Chemoattractant Following Ischemia-Reperfusion in Rat Liver. Dig. Dis. Sci. 2000, 45, 201-209. [CrossRef] [PubMed]

96. Kobayashi, T.; Hirano, K.; Yamamoto, T.; Hasegawa, G.; Hatakeyama, K.; Suematsu, M.; Naito, M. The protective role of Kupffer cells in the ischemia-reperfused rat liver. Arch. Histol. Cytol. 2002, 65, 251-261. [CrossRef] [PubMed]

97. Muller, W.A. New Mechanisms and Pathways for Monocyte Recruitment. J. Exp. Med. 2001, 194, F47-F52. [CrossRef] [PubMed]

98. Krenkel, O.; Mossanen, J.C.; Tacke, F. Immune mechanisms in acetaminophen-induced acute liver failure. Hepatobiliary Surg. Nutr. 2014, 3, 331-343. [CrossRef] [PubMed]

99. Bamboat, Z.Z.M.; Ocuin, L.M.; Balachandran, V.P.; Obaid, H.; Plitas, G.; DeMatteo, R.R.P.; Lotze, M.; Clavien, P.; Harvey, P.; Strasberg, S.; et al. Conventional DCs reduce liver ischemia/reperfusion injury in mice via IL-10 secretion. J. Clin. Investig. 2010, 120, 559-569. [CrossRef] [PubMed]

100. Colletti, L.M.; Remick, D.G.; Burtch, G.D.; Kunkel, S.L.; Strieter, R.M.; Campbell, D.A., Jr. Role of tumor necrosis factor-alpha in the pathophysiologic alterations after hepatic ischemia/reperfusion injury in the rat. J. Clin. Investig. 1990, 85, 1936-1943. [CrossRef] [PubMed]

101. Tsung, A.; Sahai, R.; Tanaka, H.; Nakao, A.; Fink, M.P.; Lotze, M.T.; Yang, H.; Li, J.; Tracey, K.J.; Geller, D.A.; et al. The nuclear factor HMGB1 mediates hepatic injury after murine liver ischemia-reperfusion. J. Exp. Med. 2005, 201, 1135-1143. [CrossRef] [PubMed] 
102. Caldwell, C.C.; Okaya, T.; Martignoni, A.; Husted, T.; Schuster, R.; Lentsch, A.B. Divergent functions of CD4+ T lymphocytes in acute liver inflammation and injury after ischemia-reperfusion. Am. J. Physiol. Gastrointest. Liver Physiol. 2005, 289, G969-G976. [CrossRef] [PubMed]

103. Camargo, C.A.; Madden, J.F.; Gao, W.; Selvan, R.S.; Clavien, P. Interleukin-6 protects liver against warm ischemia/reperfusion injury and promotes hepatocyte proliferation in the rodent. Hepatology 1997, 26, 1513-1520. [CrossRef] [PubMed]

104. Cressman, D.E.; Greenbaum, L.E.; DeAngelis, R.A.; Ciliberto, G.; Furth, E.E.; Poli, V.; Taub, R. Liver failure and defective hepatocyte regeneration in interleukin-6-deficient mice. Science 1996, 274, 1379-1383. [CrossRef] [PubMed]

105. Yamada, Y.; Kirillova, I.; Peschon, J.J.; Fausto, N. Initiation of liver growth by tumor necrosis factor: Deficient liver regeneration in mice lacking type I tumor necrosis factor receptor. Proc. Natl. Acad. Sci. USA 1997, 94, 1441-1446. [CrossRef] [PubMed]

106. Dal-Secco, D.; Wang, J.; Zeng, Z.; Kolaczkowska, E.; Wong, C.H.Y.; Petri, B.; Ransohoff, R.M.; Charo, I.F.; Jenne, C.N.; Kubes, P. A dynamic spectrum of monocytes arising from the in situ reprogramming of CCR2+ monocytes at a site of sterile injury. J. Exp. Med. 2015, 212, 447-456. [CrossRef] [PubMed]

(C) 2017 by the authors. Licensee MDPI, Basel, Switzerland. This article is an open access article distributed under the terms and conditions of the Creative Commons Attribution (CC BY) license (http:/ / creativecommons.org/licenses/by/4.0/). 